5. COHEN, op. cit.

6. Warwick County Record Office, WA6/116.

7. Victoria History of the County of Warwick, vol. VIII, p. 430.

8. Warwick County Record Office, WA6/116.

9. Warwick County Record Office, WA6/122.

10. Warwick County Record Office, WA6/121.

11. Warwick County Record Office, WA6/117.

12. COHEN, op. cit.

JOAN LANE

\title{
THE KING'S EVIL IN OXFORDSHIRE
}

IN THE Seventeenth-century heyday of the Royal Touch, the Oxfordshire village of Stanton St. John felt amply the rigours of scrofula, the King's Evil. Its residents looked eagerly to the possibility of cure by the Touch. The practice of touching for scrofula by English sovereigns was performed from Edward the Confessor to Queen Anne, while the Hanoverians by and large refrained from following in kind. ${ }^{1}$ The exiled Stuarts, meanwhile, continued to accommodate applications tendered them, claiming Divine Right and pressing suit for return to their rightful position.

The question of efficacy of the royal cure need not detain us unduly. Esmond $R$. Long, dealing some years ago with the question of the decline of tuberculosis, ${ }^{2}$ put this issue in its proper perspective. He pointed out that those patients who did not respond to the suggestion content of the touching ceremony would still, in all likelihood choose the least traumatic among a range of equally efficacious modes of therapy; heroic cures versus the king's golden angel or touch piece, bestowed with a prayer.

Evidence bearing on the problem of therapeutic efficacy, in patients where no extant records indicate relapse, and where it seems likely that the actual pathology ranged over a variety of lymphadenitides, must therefore remain at best highly presumptive. But the historian may wish to extract from patient histories a more general sense of scrofula sufferers' subsequent state(s) of health. It would, therefore, be interesting to have information on the subsequent lifespan and the frequency of repeating-relapse followed by additional intervention in the form of the Touch.

We should like to draw attention to a source of evidence for such a study which has apparently been used only infrequently by medical historians. ${ }^{3}$ English parish registers, such as those of Stanton St. John, provide records not only of baptisms, marriages, and deaths, but also the issuing by churchmen of certificates attesting to the eligibility of parishioners for the King's Touch. Such indigenous measures became necessary when the king was called upon to touch large numbers of patients in one session. Expenses were thereby also curtailed. The Rector was charged with the duty of ensuring a complement of properly needy patients, sufferers more desirous perhaps of the cure for their lymphadenitis than of Shakespeare's 'golden stamp about their necks'. The clergyman qualifies, then, as one of the earliest indigenous health officers concerned with the appropriate local distribution of health care.

Published accounts of the scrofula entries in the Stanton St. John registers have been scarce and, to some extent, misleading in that those we have found fail to indicate the accessibility of such registers. An early such account, for example, is found 


\section{News, Notes and Queries}

in a letter written on 18 March 1712/13 by the Rev. Dr. George Hickes and addressed to Thomas Hearne, the historian and antiquary. A century later, in 1813, Hickes's letter found its way into a volume produced in the manner of the 'Lives and Letters' tradition; $;^{4}$ here the editor footnoted Hickes's account of a case touched by Charles I with 'the following curious memoranda'5 relating the issuing of certificates to three individuals from the village. Some four decades still later, 1853, one Edward L. Hussey provided what is apparently the next published mention we find of the Stanton entries, only stating, however, that 'this entry is said to be in the parish register.' He quotes the Hickes footnote, as it was published in the previous 'Lives and Letters' format. A new footnote informs us, though, that 'the registers . . . have been searched without finding these entries.' 6

We have located these entries, quoted correctly in the Hickes note, in the portion of the registers maintained in the parish church of Stanton St. John (copies of another portion being in the Bodleian). The register in question reads as follows:

An account of Certificates given of Persons not before been Touchd for ye Kings Evill. Feb. 25-1683. A Certificate given concerning Tho: Grant Son of Tho: and Amy Grant.

1686. Sept. S. I gave a Certificate for Mr Masons Daughters Alice \& Avis, Who were touch'd by ye King Sept: $19^{\text {th }}$ as $\mathrm{Mr}^{\mathrm{r}}$ Mason told me.

1705. Mar: 25. I gave a Certificate concerning Ralph Gilberts son Ralph not being formerly touchd for ye Kings Evil.?

The assiduousness with which early scholarship pursued its quest need concern us less here than the possibilities of research based on records of this nature, as they come available. As demographers have been pointing out, it is possible to correlate social or biological events in subjects' life histories with their dates of baptism and death, thus generating useful and informative patient/subject cohorts. Location of the Stanton entries allows one to go on, for example, to discover that Thomas Grant of the village was twelve or thirteen when he received the Touch; he lived on to the advanced age of seventy-four. In an individual case, indeed, this case history should hardly elicit surprise, given the chronicity and the indolent course often (though not always) displayed by a disease process such as scrofula. If such records could be gathered in sufficient numbers, however, they might well allow us better to trace out shifting patterns of interaction between the disease and its host. ${ }^{8}$ We would thus be afforded a better picture of at least one chronic disease in a period of great scientific and medical interest.

\section{REFERENCES}

1. Crawfurd, Raymond, The King's Evil, Oxford, 1911.

2. LONG, Esmond R., 'The decline of tuberculosis, with special reference to the generalized form', Bull. Hist. Med., 1940, 8, 819-43.

3. In the volume on medical historiography which he recently edited, Edwin Clarke includes historical demography based on parish registers among the 'topics which will be of considerable importance to the history of medicine in the future,' but which in his book 'are obvious omissions,' (Modern Methods in the History of Medicine, London, 1971; vii). In the same volume Thomas McKeown relates present knowledge of the reduction in tuberculosis mortality to the nature of the (primarily nineteenthcentury) evidence: ibid., 'Medical issues in historical demography', 57-74; see 


\section{News, Notes and Queries}

especially 60-61. An instructive assessment of recent trends in demographic approaches to parish registers is provided by D. E. C. Eversley, 'Exploitation of Anglican Parish Registers by Aggregative Analysis', in Wrigley, E. A. (ed.), An Introduction to English Historical Demography, London, 1966. We must also note the recent groundswell of parish register publication efforts. Yet what remains perhaps the most balanced and systematic descriptive survey of the substrate with which Wrigley and his co-workers concern themselves is that of J. C. Cox, The Parish Registers of England, London, 1910. Medical historians will find of special interest ch. 9, 'The plague and other sickness', pp. 142-83; here cf. esp. pp. 179-83 on the Royal Touch for scrofula.

4. WALKER, JOHN (ed.), Letters written by eminent persons in the seventeenth and eighteenth century: to which are added, Hearne's journeys to Reading, and to Waddon Hall, the seat of Browne Willis, esq., and lives of eminent men, by John Aubrey, esq., London, 1813. This was the first published version of Aubrey's Brief Lives.

5. Ibid., pp. 250-51.

6. Hussey, EDWARD, 'On the cure of scrofulous diseases attributed to the royal touch', Archaeol. J., 1853, 10, 187-211; 189. Emphasis added.

7. The register booke for Stanton St. Johns (Robert Pepper Register); unpaginated.

8. For an earlier treatment, with respect to tuberculosis during the period here under discussion, of changes in the host-parasite relationship see John Brownlee, 'An investigation into the epidemiology of phthisis in Great Britain and Ireland', Medical Research Committee Special Reports, no. 18, 1917; cf. especially pp. 38-45. Brownlee's reliance on the London Bills of Mortality renders his approach complementary to the one we are proposing: in the former case one is looking at the proportionate mortality ascribable to tuberculosis in a sizeable population. The latter permits analysis of changes in smaller cohorts from smaller catchment areas; indeed, the most finely-grained resolution is possible, that of individual life-cycles changing over times as a consequence of shifts in the host-parasite relationship. For a more recent treatment similar to that of Brownlee, but of multiple entities in an earlier period, see T. R. Forbes, Chronicle from Aldgate: Life and Death in Shakespeare's London New Haven, 1971, pp.100-10. Cf. Cox, loc. cit. (n. 3), for examples of other parishes which may in future furnish data of this sort.

RUSSELL C. MAULITZ AND SUSAN R. MAULITZ

\section{THE ORIGINS OF MEDICAL EDUCATION OF WOMEN IN ONTARIO}

IN 1871 The National Association for Promoting the Medical Education of Women was founded in Edinburgh. It represented the combination of the efforts of a handful of pioneering female physicians who were demanding admission to the Faculty of Medicine of that university. Their efforts were being matched throughout the western world by all women who demanded the right to a career in medicine.

Women in Ontario were very much aware of this struggle. The first woman physician in Canada, Dr. Emily Stowe, had been forced to obtain her medical education in the United States, as women were not permitted to enter Canadian medical schools. She graduated in 1867 (the year of the founding of the Ontario Medical Association) from the New York Medical College and Hospital for Women. Following this she returned to Toronto in company with Dr. Jenny K. Trout. These two were permitted 